\title{
NANOCRYSTALLINE HYDROXYAPATITE PREPARED AT DIFFERENT PRECURSOR CONCENTRATIONS: THERMAL STABILITY, MORPHOLOGY AND IN VITRO CELLULAR RESPONSE
}

\author{
BANG LE THI*,, BUI DUC LONG*, TRINH VAN TRUNG*, \\ NGUYEN T. VAN THANH*, S. RAMESH***** \\ *School of Materials Science and Engineering, Hanoi University of Science and Technology, \\ No1. Dai Co Viet, Hai Ba Trung, Hanoi, Vietnam \\ **Center of Advanced Manufacturing and Material Processing, Department of Mechanical Engineering, \\ Faculty of Engineering, University of Malaya, 50603 Kuala Lumpur, Malaysia \\ ***Faculty of Engineering, Universiti Teknologi Brunei, Tungku Highway, Gadong BE1410, Brunei Darussalam \\ "E-mail: bang.lethi@hust.edu.vn
}

Submitted July 21, 2021; accepted September 10, 2021

\begin{abstract}
Keywords: Hydroxyapatite, Concentration, Bioceramics, Precipitation
Hydroxyapatite is widely used for the reconstruction of defective bones due to its similarity with the composition of bone mineral. In this research, nanocrystalline hydroxyapatite (HA) was synthesised using calcium hydroxide and phosphoric acid as starting precursors. Different concentrations of the reactants, viz. $0.5,1.0,1.5$ and $2.0 \mathrm{~mol} \cdot \mathrm{L}^{-1}$, were considered to investigate their effect on the thermal stability and morphology of the synthesised HA. The results showed that the synthesised HA exhibited rod-like shaped particles having sizes in the range of 73.4 to $114.5 \mathrm{~nm}$ in length and 14.9 to 20.7 $\mathrm{nm}$ in width. The HA produced at the reactant concentration of 0.5 and $1.0 \mathrm{~mol} \cdot \mathrm{L}^{-1}$ was thermally stable up to $1200{ }^{\circ} \mathrm{C}$ and did not exhibit any secondary phase. However, the HA prepared at the $1.5 \mathrm{~mol} \cdot \mathrm{L}^{-1}$ concentration decomposed into tricalcium phosphate at $1000{ }^{\circ} \mathrm{C}$ while the HA prepared at $2.0 \mathrm{~mol} \cdot \mathrm{L}^{-1}$ decomposed at $1200{ }^{\circ} \mathrm{C}$. It was also found that the size of the particles increased with increasing reactant concentrations. The HA produced from the reactant concentration of $1.0 \mathrm{~mol} \cdot \mathrm{L}^{-1}$ was found to be optimum in terms of the powder characteristics and the in vitro cell studies indicated that osteoblast cells proliferated well on the synthesised HA, thus confirming the biocompatible nature of the produced bioceramic.
\end{abstract}

\section{INTRODUCTION}

Hydroxyapatite ( $\left.\mathrm{HA}, \mathrm{Ca}_{10}\left(\mathrm{PO}_{4}\right)_{6}(\mathrm{OH})_{2}\right)$ is the most important ceramic among the calcium phosphate compounds since it is found in natural hard tissues as a mineral inorganic phase [1-3]. In order to produce synthetic HA powders with the desired properties, wet-chemical methods (precipitation, hydrothermal techniques and hydrolysis of other calcium phosphates) and dry processes (solid-state reactions) can be used. Depending upon the technique, materials with various morphology, stability and level of crystallinity can be obtained [4-6].

In general, wet-chemical methods allow the production of materials with good crystallinity, physiological stability, and with the morphological characteristics of hard tissue [3, 7]. However, the physical, chemical, and mechanical properties of the final product depend on the experiment conditions, i.e., starting precursor, reaction temperature, $\mathrm{pH}$ and concentrations [8-11]. It was reported that different reaction temperatures affected the morphology of the precipitated particles, thermal stability as well as the degree of crystallinity of the product $[8,9,12]$. For example, Lazic et al. [8] prepared HA from alkaline aqueous solutions of a $\mathrm{Ca}(\mathrm{OH})_{2}$ suspension, which was prepared by slurring $\mathrm{CaO}$ powder in distilled water and $\mathrm{H}_{3} \mathrm{PO}_{4}$. The results showed that the precipitation conditions had a significant effect on the thermal stability of the HA. At a temperature of $900{ }^{\circ} \mathrm{C}$, the presence of impurity phases, such as $\mathrm{CaO}, \beta$-tricalcium phosphate (TCP), was detected in the samples prepared at low reaction temperatures $\left(22^{\circ} \mathrm{C}\right.$ and $\left.70^{\circ} \mathrm{C}\right)$. Nano-size HA was synthesised [13] using two different precipitation routes: from calcium nitrate with $\left(\mathrm{NH}_{4}\right)_{2} \mathrm{HPO}_{4}$ and from calcium hydroxide with $\mathrm{H}_{3} \mathrm{PO}_{4}$. The reaction was carried out at either 40 or $70{ }^{\circ} \mathrm{C}$. At higher precipitation temperatures, the degree of the crystallisation increased. However, except for the sample which was prepared from calcium hydroxide that retained the HA phase 
up to $1300{ }^{\circ} \mathrm{C}$, the remaining samples showed the appearance of $\beta$-TCP above $800{ }^{\circ} \mathrm{C}$ and of $\alpha$-TCP from $1200{ }^{\circ} \mathrm{C}$ onwards.

On the other hand, the concentration of the reactants is one of the key factors affecting the thermal stability of the powder. In a study [9], precipitated HA was prepared from calcium nitrate and an ammonium hydrogen orthophosphate solution at different concentrations of $0.5,1.0$ and $2.0 \mathrm{~mol} \cdot \mathrm{L}^{-1}$. The process was carried out at 25,70 and $100{ }^{\circ} \mathrm{C}$ under continuous stirring. It was found that, at low reaction temperatures (below $100{ }^{\circ} \mathrm{C}$ ) and a high concentration $\left(2 \mathrm{~mol} \cdot \mathrm{L}^{-1}\right)$, all the HA powders decomposed into $\mathrm{CaHPO}_{4}, \mathrm{CaO}$ and TCP phases.

Researches have shown that by using $\mathrm{Ca}(\mathrm{OH})_{2}$ and $\mathrm{H}_{3} \mathrm{PO}_{4}$ with a $\mathrm{Ca} / \mathrm{P}$ ratio of 1.67 , HA with nano-size particles and high purity could be synthesised $[6,8,14,15]$. In addition, pure HA could be produced at temperatures below $100{ }^{\circ} \mathrm{C}$ mainly due to the lower supersaturation of the $\mathrm{Ca}(\mathrm{OH})_{2}$ solubility [16-18]. However, at a lower reaction temperature, the precipitated HA decomposed into other phases, such as TCP and $\mathrm{CaO}$, during the heating process from $900{ }^{\circ} \mathrm{C}$ onwards [8]. Moreover, to obtain nano-size single phase HA particles with high thermal stability, the reactions were always carried out at high temperatures in the range of 70 to $100{ }^{\circ} \mathrm{C}$ [9]. The aim of this research work was to investigate the effect of the reactant concentration on the purity, morphology and thermal stability of $\mathrm{HA}$ synthesised at $40{ }^{\circ} \mathrm{C}$ by a precipitation method. In addition, the biocompatibility of the synthesised HA was evaluated using MC3T3-E1 cell-lines by cell viability and cell proliferation assays.

\section{EXPERIMENTAL}

\section{Material and methods}

A precipitation method was used to prepare hydroxyapatite (HA), using $\mathrm{Ca}(\mathrm{OH})_{2}(96 \%$ purity, Fluka) and $\mathrm{H}_{3} \mathrm{PO}_{4}(15 \mathrm{M}$, Merck) as described in a previous study [3]. In this research, a $\mathrm{Ca}(\mathrm{OH})_{2}$ solution and an $\mathrm{H}_{3} \mathrm{PO}_{4}$ solution were prepared at different concentration solutions, i.e., $0.5,1.0,1.5$ and $2.0 \mathrm{~mol} \cdot \mathrm{L}^{-1}$. The prepared $\mathrm{Ca}(\mathrm{OH})_{2}$ and $\mathrm{H}_{3} \mathrm{PO}_{4}$ solutions were mixed at the stoichiometric $\mathrm{Ca} / \mathrm{P}$ ratio of 1.67 for hydroxyapatite. In a typical mixture, the $\mathrm{H}_{3} \mathrm{PO}_{4}$ solution was gradually added to the $\mathrm{Ca}(\mathrm{OH})_{2}$ suspension under vigorous stirring at $400 \mathrm{rpm}$. The reaction was performed in a water bath at $40{ }^{\circ} \mathrm{C}$. The $\mathrm{pH}$ of the reaction was monitored by a $\mathrm{pH}$ meter and maintained at about 9 by adding some ammonia solution $\left(\mathrm{NH}_{4} \mathrm{OH} 29 \%\right.$, J.T. Baker, USA). After the reaction had completed, the mixture was allowed to mature at room temperature for $24 \mathrm{~h}$. Subsequently, it was filtered and washed with deionised water before drying in an oven at $90{ }^{\circ} \mathrm{C}$ for $12 \mathrm{~h}$. The dried HA powders were then ground with an agate pestle and mortar. The as-prepared powder was heattreated at different temperatures of $1000{ }^{\circ} \mathrm{C}$ and $1200{ }^{\circ} \mathrm{C}$ for $1 \mathrm{~h}$ in a furnace (Lenton, 1500) to study the thermal stability of the synthesised powder. For identification purposes, the samples were labelled according to the concentration used to prepare the HA, for example, HA0.5 refers to the powder prepared at the reactant concentration of $0.5 \mathrm{M}$.

\section{Characterisation}

A thermal analysis of the as-prepared HA powder was carried out by using a STA 409 PC Luxx (Netzsch, Germany). The temperature range used was from room temperature up to $1200{ }^{\circ} \mathrm{C}$ using a heating rate of $10{ }^{\circ} \mathrm{C} \cdot \mathrm{min}^{-1}$ in an inert atmosphere. The as-synthesised and heat-treated powders were characterised using an X-ray diffractometer (XRD; D5000 Siemens) for the phase identification. A diffraction peak at about $25.9^{\circ}(2 \theta)$ was used to calculate the crystallite size of the sample since it was sharper and isolated from the other peaks. The morphology of the particles was observed by using high-resolution scanning electron microscopy (FESEM, SUPRA 35VP-24-58) and transmission electron microscopy (TEM, Philips CM12). Powder density was measured using a gas pycnometer. The BET (Brunauer, Emmet and Teller) specific surface area was determined by using BET Flow Sorb 2300-Micromeritics with liquid nitrogen.

The heat-treated HA pellets at $1200{ }^{\circ} \mathrm{C}$ (app. $\phi 12 \times$ $\times 3 \mathrm{~mm}$ ) were used in the cell study. An MC3T3-E1 cellline was used to evaluate the tissue compatibility of the HA obtained through the cell attachment ability and cell morphologies on the samples. Cells were loaded on the sample at a density of $3 \times 10^{4}$ cells/well and incubated for 4 h, 1 day and 3 days. After each time point, the samples were rinsed gently with phosphate buffer saline, fixed with $3 \%$ glutaraldehyde (SIGMA) in a sodium phosphate buffer at $4{ }^{\circ} \mathrm{C}$ for $2 \mathrm{~h}$. Subsequently, the samples with the cells were dehydrated in a graded series of ethanol solutions $(50,60,70,80,90$ and $100 \%)$ for $30 \mathrm{~min}$ each at $4{ }^{\circ} \mathrm{C}$. The samples were dried in hexamethyldisilazane (HMDS, Wako, Japan). $500 \mu \mathrm{L}$ of HMDS was added to the cell area requiring fixation for $30 \mathrm{~min}$. This procedure was repeated three times to totally remove the ethanol. After complete evaporation of HMDS, the samples were sputtered with a thin gold film and visualised by SEM.

For the cell proliferation, cells were cultured at a density of $1 \times 10^{4}$ cells per well $(n=4)$ under the conditions explained above for the proliferation assessment. The culture medium was changed every 2 days. At 2, 4 and 6 days, the proliferation of the cells was determined using a cell counting kit-8 (CCK-8; Dojindo, Kumamoto, Japan). After washing with PBS three times, the samples were incubated in a growth medium supplemented with a CCK-8 solution at $37{ }^{\circ} \mathrm{C}$ for $1 \mathrm{~h}$, and $100 \mu \mathrm{L}$ of the resulting medium was then transferred to a 96-well plate. The absorbance was 
measured at $450 \mathrm{~nm}$ with a microplate reader (M200; Tecan Group Ltd., Victoria, Australia).

The means and standard derivation (S.D.) of the data were calculated. The statistical significance between the test groups was evaluated by a one-way analysis of variance (ANOVA) and Tukey's multiple comparison cell proliferation experiment. $\mathrm{p}<0.05$ was considered statistically significant.

\section{RESULTS AND DISCUSSIONS}

Thermal analysis

The Thermogravimetry/Differential Scanning Calorimetry (TG/DSC) curve of the as-prepared HA powders prepared at the different concentrations of $0.5 \mathrm{~mol} \cdot \mathrm{L}^{-1}(\mathrm{HA} 0.5), 1 \mathrm{~mol} \cdot \mathrm{L}^{-1}(\mathrm{HA} 1), 1.5 \mathrm{~mol} \cdot \mathrm{L}^{-1}$ (HA1.5) and $2 \mathrm{~mol} \cdot \mathrm{L}^{-1}$ (HA2) are shown in Figures 1a-d, respectively. Generally, the first endothermic peak below $100{ }^{\circ} \mathrm{C}$ in all four samples corresponds to the weight loss in this temperature range and is attributed to the evaporation of adsorbed water. In addition, there are no endothermic peaks present where the DSC results exhibit the smooth curves for the HA0.5, HA1 and HA2 samples (Figure 1a, b, d), and the corresponding TG curves showed little mass change over the temperature range of $600-1200{ }^{\circ} \mathrm{C}$. This indicated that the thermal stability of the HA was not disrupted and there was no formation of a secondary phase after heat treatment.
However, on the DSC curve of the HA1.5 sample (Figure 1c), there is a very small endothermic peak at $959.5{ }^{\circ} \mathrm{C}$ corresponding to a weight loss of about $0.46 \%$ from $900-1200{ }^{\circ} \mathrm{C}$. This endothermic peak could be attributed to the transformation of HA into $\beta$-TCP as reported by other workers $[13,19,20]$. The thermal stability of all four samples in the present work was confirmed by XRD analysis before and after heat treatment at $1000{ }^{\circ} \mathrm{C}$ and $1200{ }^{\circ} \mathrm{C}$, as discussed in the subsequent section.

According to the literature [8], the decomposition of calcium deficient apatite at temperatures below $1000{ }^{\circ} \mathrm{C}$ proceeded according to the reaction:

$\mathrm{Ca}_{10}\left(\mathrm{HPO}_{4}\right)\left(\mathrm{PO}_{4}\right)_{6-\mathrm{x}} \rightarrow \mathrm{xCa}_{9}\left(\mathrm{PO}_{4}\right)_{6}(\beta)+(1-\mathrm{x}) \mathrm{Ca}_{10}\left(\mathrm{PO}_{4}\right)_{6}$ $(\mathrm{OH})_{2}$,

Therefore, the endothermic peak that appeared in the HA1.5 sample curve is likely due to the decomposition of hydroxyapatite to $\beta-\mathrm{Ca}_{3}\left(\mathrm{PO}_{4}\right)_{2}$. On the other hand, there is a significant decrease in the DSC curve above $1000{ }^{\circ} \mathrm{C}$ in sample at $2.0 \mathrm{~mol} \cdot \mathrm{L}^{-1}$ (Figure 1d) compared to the other curves. This can be explained by the severe decomposition of hydroxyapatite $[8,9,21]$ that takes place at a higher temperature $\left(1200{ }^{\circ} \mathrm{C}\right)$ according to either of the below reactions.

$$
\mathrm{Ca}_{10}\left(\mathrm{PO}_{4}\right)_{6}(\mathrm{OH})_{2} \rightarrow 2 \mathrm{Ca}_{3}\left(\mathrm{PO}_{4}\right)_{2}(\alpha)+\mathrm{Ca}_{4} \mathrm{P}_{2} \mathrm{O}_{9}+\mathrm{H}_{2} \mathrm{O}
$$
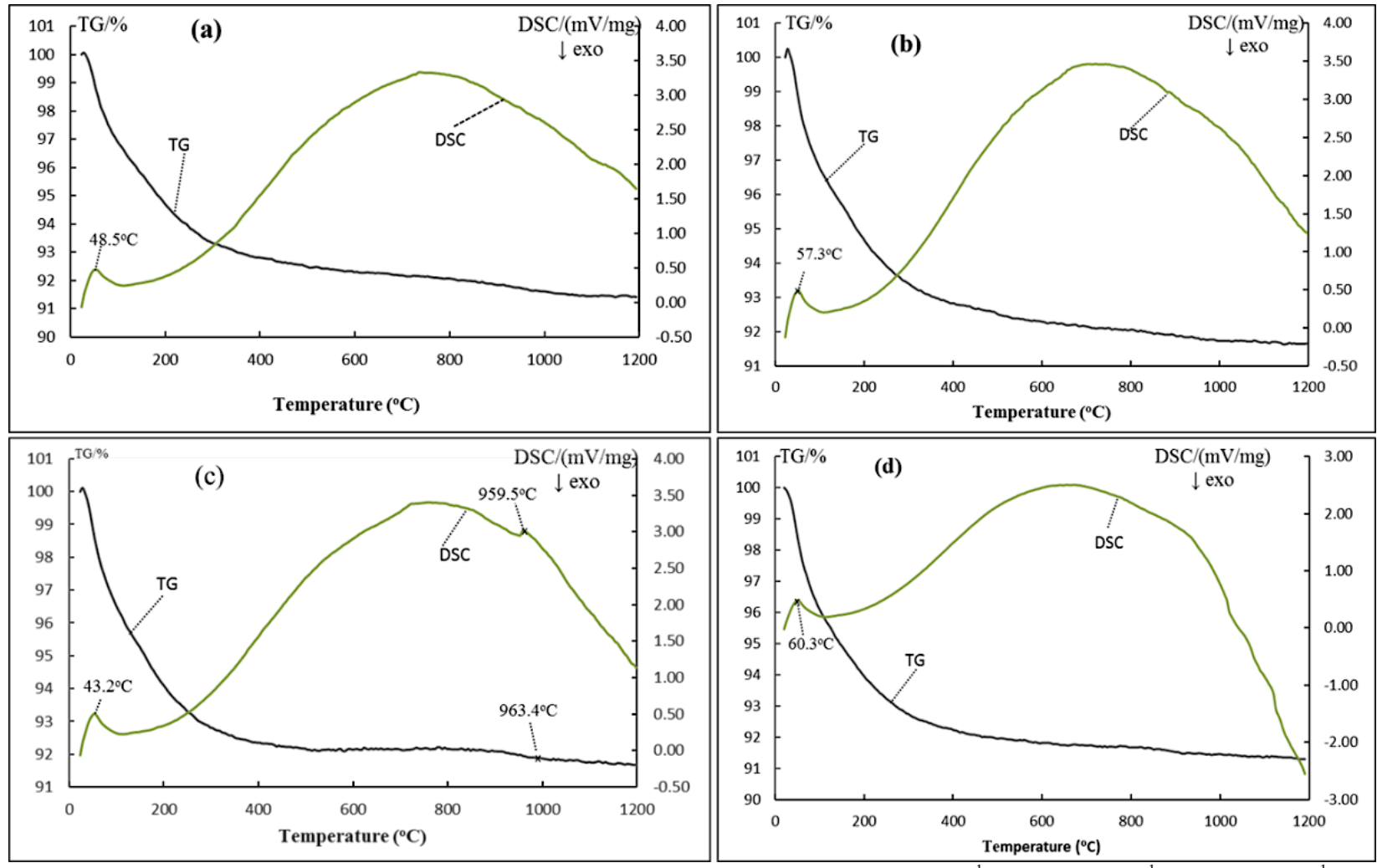

Figure 1. TG/DSC curves of the samples at different reactant concentrations: (a) $0.5 \mathrm{~mol} \cdot \mathrm{L}^{-1}$, (b) $1.0 \mathrm{~mol} \cdot \mathrm{L}^{-1}$, (c) $1.5 \mathrm{~mol} \cdot \mathrm{L}^{-1}$ and (d) $2.0 \mathrm{~mol} \cdot \mathrm{L}^{-1}$ 
$\mathrm{Ca}_{10}\left(\mathrm{PO}_{4}\right)_{6}(\mathrm{OH})_{2} \rightarrow 2 \mathrm{Ca}_{3}\left(\mathrm{PO}_{4}\right)_{2}(\alpha)+\mathrm{Ca}_{3} \mathrm{P}_{2} \mathrm{O}_{8}+\mathrm{CaO}$ $+\mathrm{H}_{2} \mathrm{O}$

At this juncture, more in-depth studies such as using XRD high temperature attachment could be carried out to gain more insights into the phase decomposition of the HA.

\section{XRD analysis and specific surface area measurement}

Figure 2 shows the XRD pattern of the as-prepared powders. The XRD patterns indicate that a poor crystalline nature of typical apatite crystal structure with broad diffracted peaks could be obtained without any extraneous phases. It means that pure HA was obtained at all concentrations.

Figures 3-4 show the XRD patterns of the HA powders after being heat-treated at $1000^{\circ} \mathrm{C}$ and $1200^{\circ} \mathrm{C}$ for 1 $\mathrm{h}$, respectively. It was found that, at $1000^{\circ} \mathrm{C}$ (Figure 3 ), all the samples are stable pure HA except for sample HA1.5 which shows two very small peaks of $\beta$-TCP observed at $31.208^{\circ}$ and $34.598^{\circ}(2 \theta)$. Upon heat treatment at $1200^{\circ} \mathrm{C}$ (Figure 4 ), the XRD pattern did not indicate any new crystalline phases in the HA0.5 and HA1 samples, i.e.,

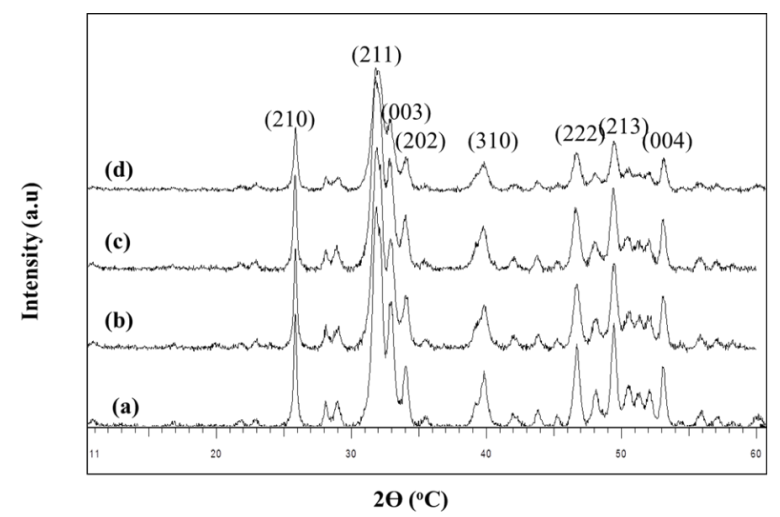

Figure 2. XRD patterns of the as-prepared HA powders at different concentrations of reactants: (a) $0.5 \mathrm{~mol} \cdot \mathrm{L}^{-1}$, (b) $1.0 \mathrm{~mol} \cdot \mathrm{L}^{-1}$, (c) $1.5 \mathrm{~mol} \cdot \mathrm{L}^{-1}$ and (d) $2.0 \mathrm{~mol} \cdot \mathrm{L}^{-1}$.

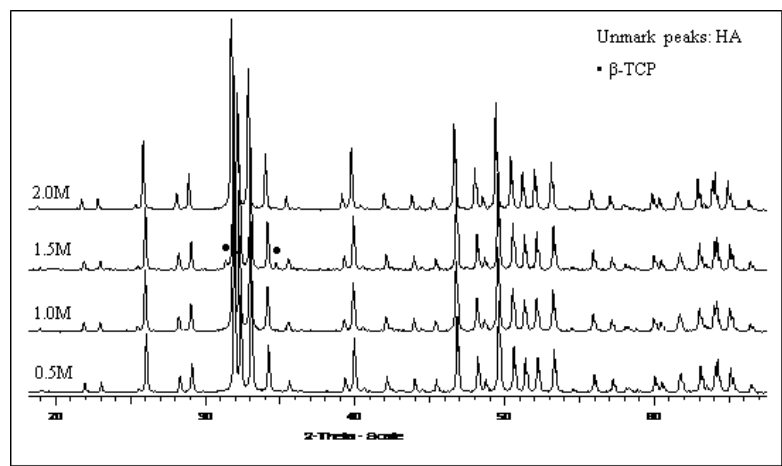

Figure 3. XRD patterns of the HA powders prepared at different concentrations and heat treated at $1000{ }^{\circ} \mathrm{C}$. the XRD patterns only match the HA reference pattern (ICDD card No. 9-432), indicating the stability of the HA powders at high temperatures. However, small peaks of $\alpha$-TCP were detected in the sample prepared at $2.0 \mathrm{M}$ (HA2 sample) and this is due to the decomposition of HA to form $\alpha$-TCP at $1200{ }^{\circ} \mathrm{C}$ while HA1.5 decomposed at $1000{ }^{\circ} \mathrm{C}$

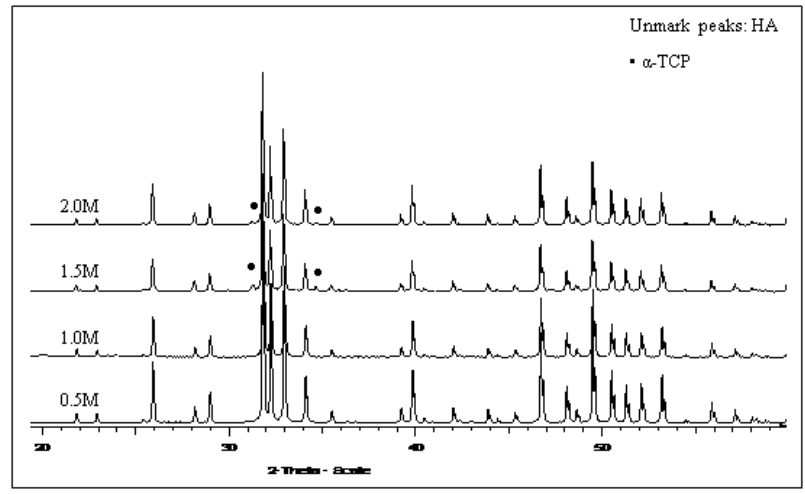

Figure 4. XRD patterns of the HA powders prepared at different concentrations and heat-treated at $1200^{\circ} \mathrm{C}$.

It is established in the literature $[22,23]$ that the transition from $\beta$-TCP to $\alpha$-TCP proceeds at high temperatures above $1125^{\circ} \mathrm{C}$. It was reported [9] that pure HA powders could not be produced at concentrations of 1.5 and $2.0 \mathrm{~mol} \cdot \mathrm{L}^{-1}$ when treated at $1200{ }^{\circ} \mathrm{C}$ except for samples prepared at concentrations of 0.5 and $1.0 \mathrm{~mol} \cdot \mathrm{L}^{-1}$ synthesised at a high reaction temperature of $100^{\circ} \mathrm{C}$. The amount of $\beta$-TCP present in the HA was not determined; however, it was reported that depending of the powder history, a small amount of $\beta$-TCP $(1-3 \%)$ was formed when treated at temperatures of $1200-1250{ }^{\circ} \mathrm{C}$ and about $3 \% \quad \alpha$-TCP was present when treated above $1250{ }^{\circ} \mathrm{C}[21]$.

Table 1 summarises the specific surface area and crystallite size of the as-precipitated HA synthesised at different concentrations. It was found that sample HA1 recorded the highest specific surface area of $78.98 \mathrm{~m}^{2} \cdot \mathrm{g}^{-1}$ and the specific surface area decreased when the concentration was increased from $1.0 \mathrm{M}$ to $1.5 \mathrm{M}$ and $2.0 \mathrm{M}$. The crystallite size, however, did not show significant changes with an increasing reactant concentration. The average particle size of the powders as given in Table 1 was measured from about 36 to 78 particles taken from the Transmission electron microscopy (TEM) images. The results showed that the aspect ratio increased when the concentration of the reactant increased. This phenomenon is believed to be due to the increase in the length of the particles due to the higher growth rate experience by the HA crystals in the $c$-axis $[4,9]$. 
Table 1. Specific surface area, crystallite size and particle size of the as-synthesised HA at different reactant concentrations.

\begin{tabular}{lccccc}
\hline \multirow{2}{*}{ Sample } & \multicolumn{2}{c}{ Specific Crystallite } & \multicolumn{3}{c}{ Particle size } \\
\cline { 4 - 6 } & $\begin{array}{c}\text { surface } \\
\left(\mathrm{m}^{2} \cdot \mathrm{g}^{-1}\right)\end{array}$ & $\begin{array}{c}\text { size } \\
(\mathrm{nm})\end{array}$ & $\begin{array}{c}\text { length } \\
(\mathrm{nm})\end{array}$ & $\begin{array}{c}\text { Avg. } \\
\text { breadth } \\
(\mathrm{nm})\end{array}$ & $\begin{array}{c}\text { Avg. } \\
\text { Aspect ratio } \\
(\mathrm{nm})\end{array}$ \\
\hline HA0.5 & 68.96 & 21.6 & $79 \pm 4.2$ & $18.6 \pm 1.8$ & 4.4 \\
HA1 & 78.98 & 20.1 & $85.3 \pm 2.4$ & $17.9 \pm 0.5$ & 4.7 \\
HA1.5 & 62.56 & 20.4 & $89.2 \pm 2.9$ & $17.1 \pm 0.5$ & 5.2 \\
HA2 & 64.69 & 18.9 & $92.8 \pm 4.6$ & $18.4 \pm 0.7$ & 5.1 \\
\hline
\end{tabular}

Morphological analysis and density measurement

The morphology and the particle size of the assynthesised HA powders were studied by TEM as shown in Figure 5. The microstructure of the HA particles was observed to be a rod-like shape with a particle size in the range of 73.4 to $114.5 \mathrm{~nm}$ in length and 14.9 to $20.7 \mathrm{~nm}$ in width. This result demonstrated that nano-particles could be successfully produced by the precipitation method.

Figures 6 and 7 show the representative FESEM images of the HA powders heat-treated at $1000{ }^{\circ} \mathrm{C}$ and $1200{ }^{\circ} \mathrm{C}$ for $1 \mathrm{~h}$, respectively. The heat-treated HA powders appear to be highly agglomerated with relatively uniform spherical shape particles. The size of the particles was found to increase with the increasing heat treatment temperature $[24,25]$. Moreover, it is noticeable that the HA1.5 and HA2 samples, which decomposed into $\beta$-TCP after heat treatment, showed the presences of pores (Figure 7c, d). This phenomenon could be explained from the fact that the decomposition temperature is strongly dependent on the characteristic of the HA powders. During decomposition, a large amount of water is formed. It is hypothesised that as the water forced its way out, which created many pores in the heat-treated powders [9]. As a result, the density of the heat-treated powder of HA1.5 and HA2 samples decrease when compared to that of the HA0.5 and HA1 samples (Table 2).

The properties of the heat-treated HA powders after heat treatment at $1000{ }^{\circ} \mathrm{C}$ and $1200{ }^{\circ} \mathrm{C}$ are given in Table 2. Three different FESEM images of each sample were used to measure the particle size using ImageJ soft-ware. It can be seen that the HA1 sample exhibited the smallest particles which were about $0.53 \mu \mathrm{m}$ at $1200{ }^{\circ} \mathrm{C}$ while the remaining samples have a particle size in the range of $0.59-0.82 \mu \mathrm{m}$ (see Table 2). Although the differences in the particle size among the evaluated samples is obvious, the crystallite size did not change significantly when treated at $1200{ }^{\circ} \mathrm{C}$. This due to the fact that HA exhibited a polycrystalline structure. The result indicated that the reactant concentration influences the particle size, but not the crystallite size of the HA
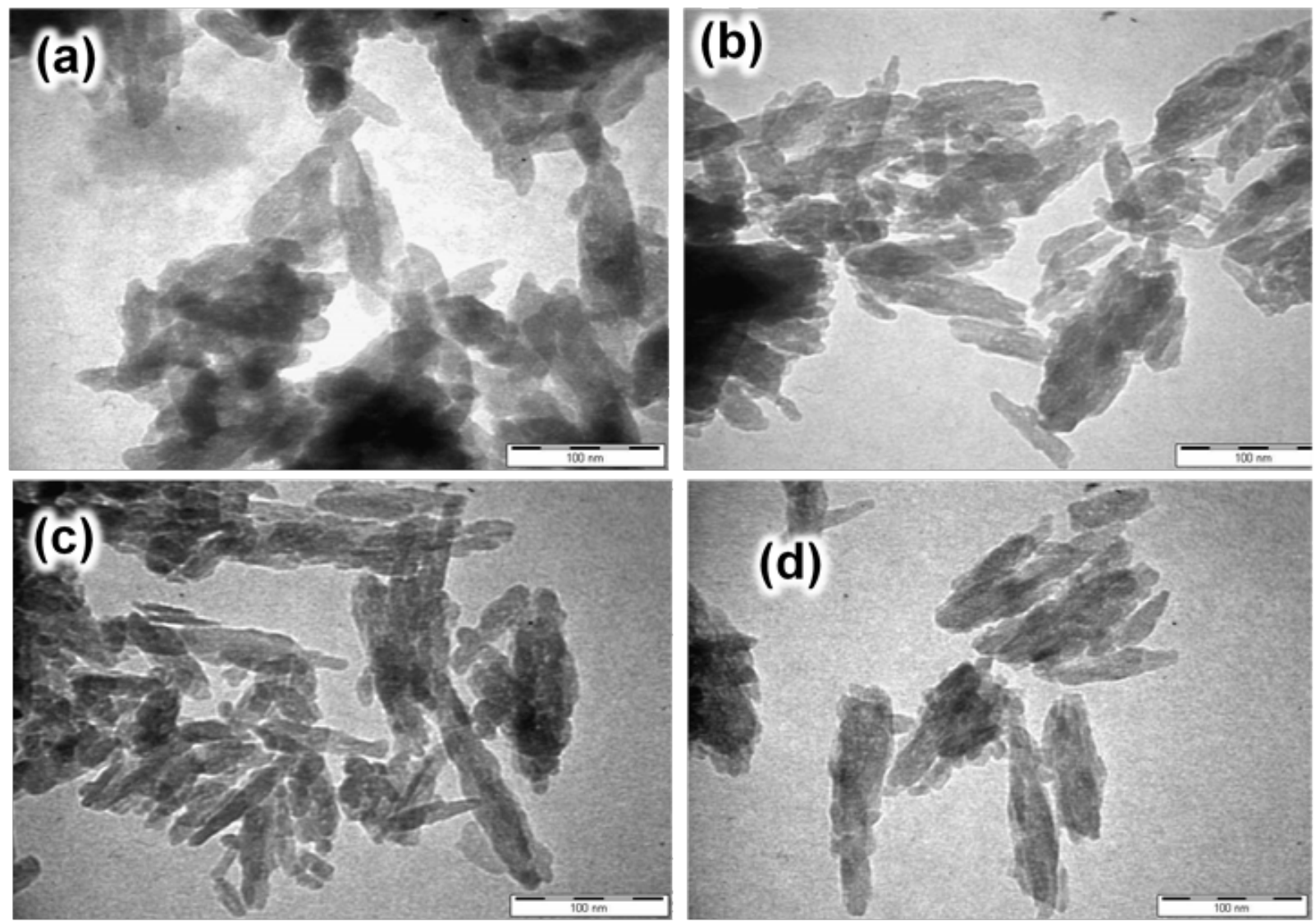

Figure 5. TEM micrographs of the HA prepared at different concentrations of reactants: (a) $0.5 \mathrm{~mol} \cdot \mathrm{L}^{-1}$, (b) $1.0 \mathrm{~mol} \cdot \mathrm{L}^{-1}$, (c) $1.5 \mathrm{~mol} \cdot \mathrm{L}^{-1}$ and (d) $2.0 \mathrm{~mol} \cdot \mathrm{L}^{-1}$. 

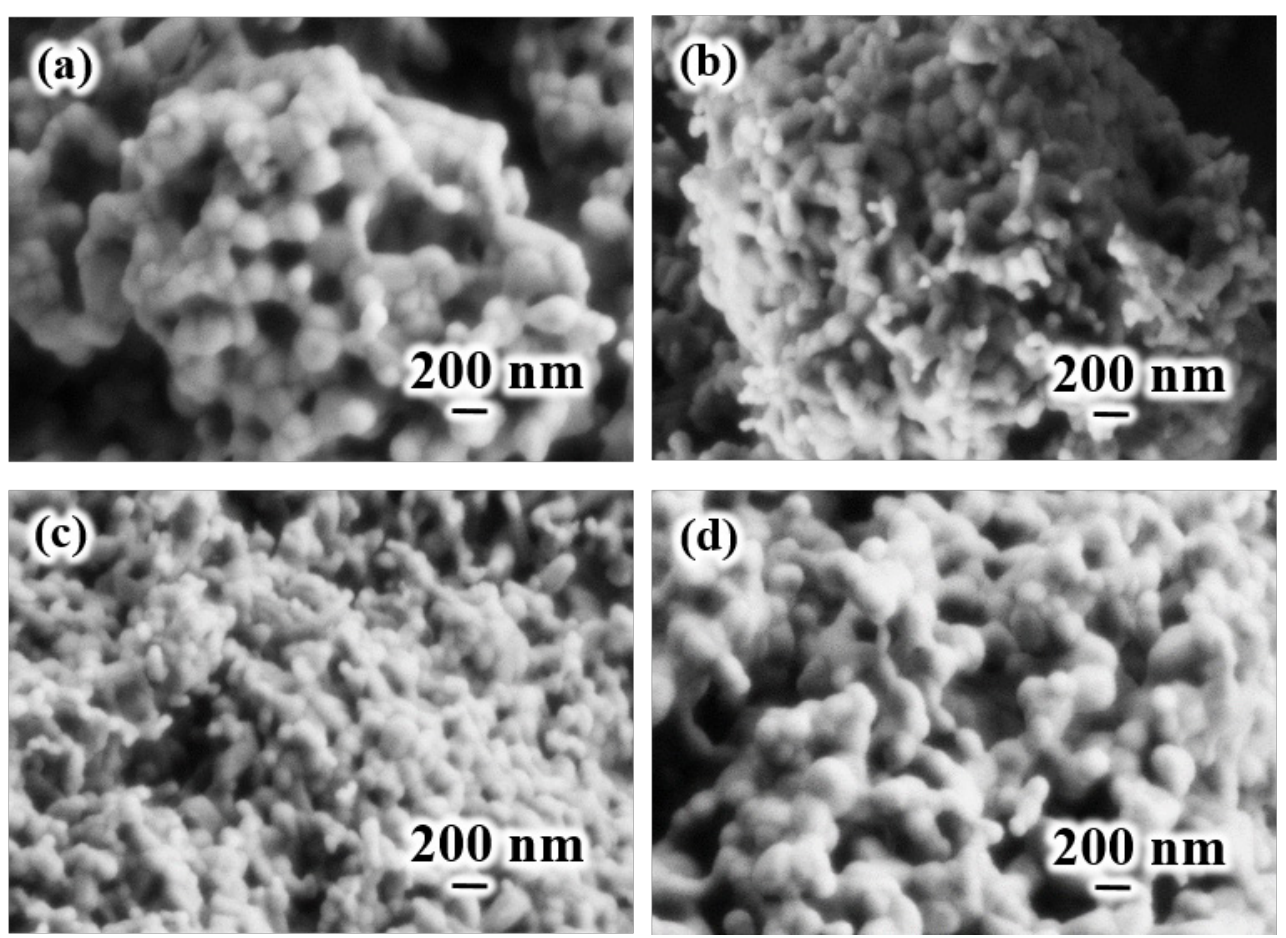

Figure 6. SEM morphology of the heat-treated $\mathrm{HA}$ at $1000{ }^{\circ} \mathrm{C}$ derived from different starting reactant concentrations: (a) $0.5 \mathrm{~mol} \cdot \mathrm{L}^{-1}$, (b) $1.0 \mathrm{~mol} \cdot \mathrm{L}^{-1}$, (c) $1.5 \mathrm{~mol} \cdot \mathrm{L}^{-1}$ and (d) $2.0 \mathrm{~mol} \cdot \mathrm{L}^{-1}$.
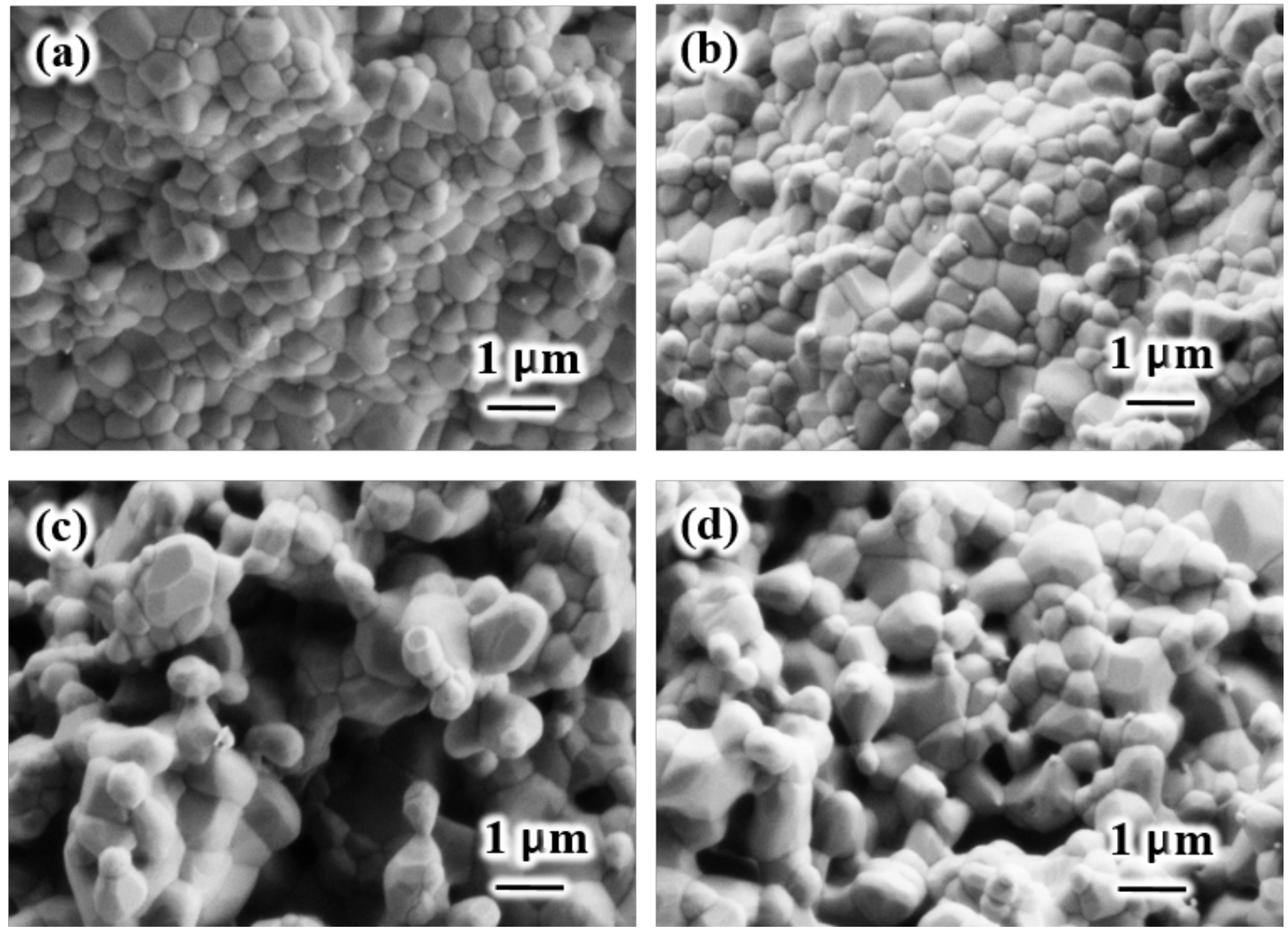

Figure 7. SEM morphology of the heat-treated HA at $1200{ }^{\circ} \mathrm{C}$ derived from different starting reactant concentrations: (a) $0.5 \mathrm{~mol} \cdot \mathrm{L}^{-1}$, (b) $1.0 \mathrm{~mol} \cdot \mathrm{L}^{-1}$, (c) $1.5 \mathrm{~mol} \cdot \mathrm{L}^{-1}$ and (d) $2.0 \mathrm{~mol} \cdot \mathrm{L}^{-1}$.

powders, i.e., the lower the concentration, the smaller the particle size obtained.

It can be observed from Table 2, the density of the calcined HA increases with an increase in the calcination temperature and the density range was $2.57-2.83 \mathrm{~g} \cdot \mathrm{cm}^{-3}$ which is around $81.3-89.5 \%$ compared to the theoretical density of the HA. It was reported that the relative density increases as the sintering temperature increases and reaches about $95 \%$ depending on the processing methods [6, 16, 26]. For example, the density was 
Nanocrystalline hydroxyapatite prepared at different precursor concentrations: thermal stability, morphology ...

Table 2. Crystallite size from the XRD data, grain size from the SEM observation and density of the samples obtained for the samples heat-treated at $1000^{\circ} \mathrm{C}$ and $1200{ }^{\circ} \mathrm{C}$.

\begin{tabular}{lcccccc}
\hline & \multicolumn{3}{c}{ At $1000{ }^{\circ} \mathrm{C}$} & At $1200{ }^{\circ} \mathrm{C}$ \\
\cline { 2 - 7 } Sample & $\begin{array}{c}\text { Density } \\
\left(\mathrm{g} \cdot \mathrm{cm}^{-3}\right)\end{array}$ & $\begin{array}{c}\text { Crystallite } \\
\text { size }(\mathrm{nm})\end{array}$ & $\begin{array}{c}\text { Particle } \\
\text { size }(\mathrm{nm})\end{array}$ & $\begin{array}{c}\text { Density } \\
\left(\mathrm{g} \cdot \mathrm{cm}^{-3}\right)\end{array}$ & $\begin{array}{c}\text { Crystallite } \\
\text { size }(\mathrm{nm})\end{array}$ & $\begin{array}{c}\text { Particle } \\
\text { size }(\mathrm{nm})\end{array}$ \\
\hline HA0.5 & 2.63 & 81 & $104 \pm 4$ & 2.83 & 147 & $590 \pm 7$ \\
HA1 & 2.69 & 66 & $97 \pm 3$ & 2.83 & 148 & $530 \pm 7$ \\
HA1.5 & 2.63 & 89 & $156 \pm 6$ & 2.69 & 151 & $820 \pm 8$ \\
HA2 & 2.57 & 92 & $140 \pm 4$ & 2.65 & 150 & $790 \pm 4$ \\
\hline
\end{tabular}
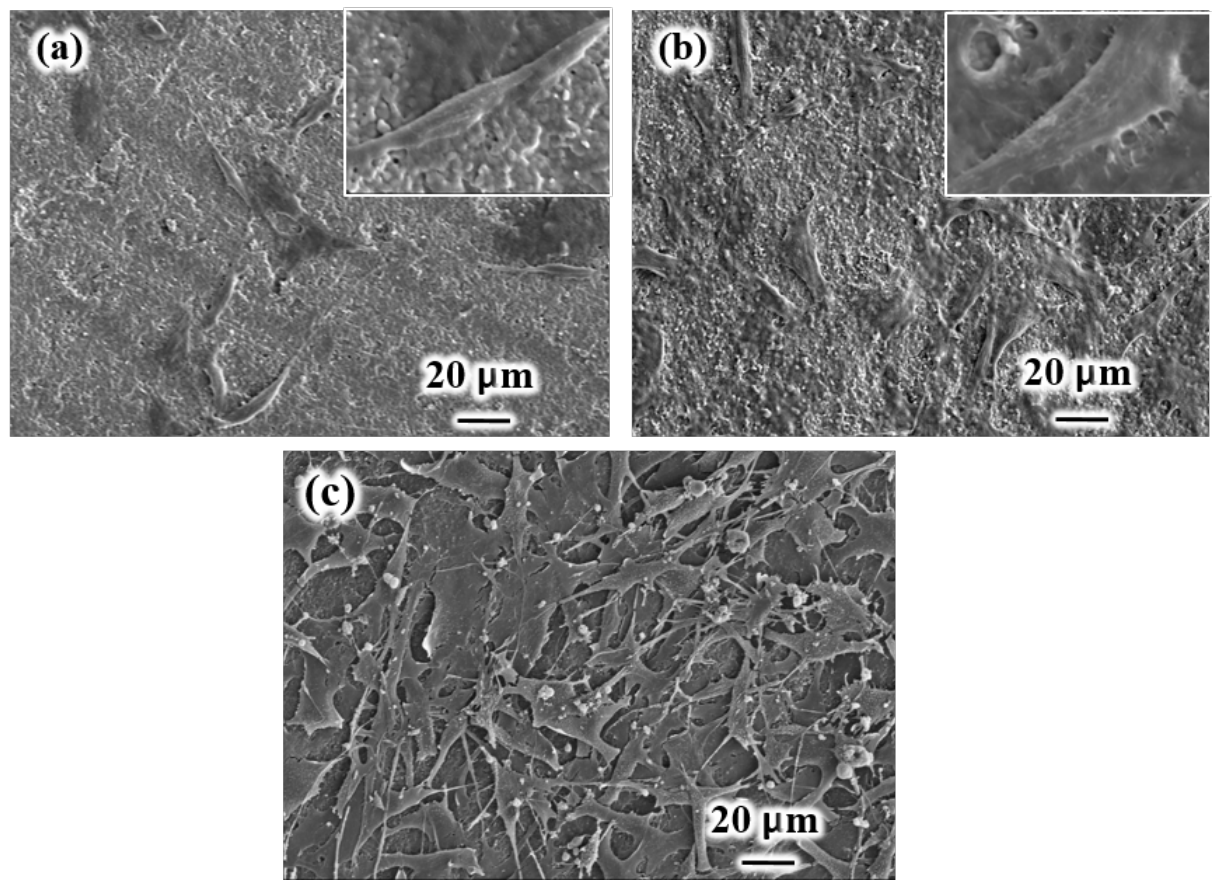

Figure 8. SEM morphology of the cells cultured on the heat-treated HA at $1200{ }^{\circ} \mathrm{C}$ after incubation for (a) 4 hours, (b) 1 day, (c) 3 days.

found to decrease significantly in the case of chemical decomposition at $1350{ }^{\circ} \mathrm{C}[17,24]$. In this study, upon increasing the heat treatment temperature, the density of the sample increased (Table 2). The lower density of the sample can be explained by the incomplete densification $[18,25]$ of the sample at $1000{ }^{\circ} \mathrm{C}$ compared to that at $1200{ }^{\circ} \mathrm{C}$. In addition, due to the decomposition, the samples produced at a reactant concentration of 1.5 and $2.0 \mathrm{~mol} \cdot \mathrm{L}^{-1}$ had a lower density compared to the other samples at certain temperatures. A similar result was also obtained previously [9] in which the sample prepared at a reactant concentration of $2.0 \mathrm{~mol} \cdot \mathrm{L}^{-1}$ and $100{ }^{\circ} \mathrm{C}$ has the lowest density after heat treatment at $1200{ }^{\circ} \mathrm{C}$ as compared to other concentrations $\left(0.5\right.$ and $\left.1 \mathrm{~mol} \cdot \mathrm{L}^{-1}\right)$.

\section{Biocompatibility evaluation}

In order to demonstrate the biocompatibility of the derived HA through an in vitro cell study in terms of the cell attachment and proliferation, the sample prepared at the $1 \mathrm{~mol} \cdot \mathrm{L}^{-1}$ (HA1) precursor concentration was selected since it exhibited the optimum properties and thermal stability when treated at $1200{ }^{\circ} \mathrm{C}$. The SEM images images (Figure 8) show the morphological feature of the osteoblast-like cells cultured on sample HA1 after $4 \mathrm{~h}$, 1 day and 3 days of incubation.

The evaluation of the biocompatibility is a primary step to assess the biological behaviour of biomaterials. Significant attachment to the surface is necessary for the cells to spread and differentiate [27]. The results of the cell attachment showed that, after 4 hours of incubation (Figure 8a), the cells are observed to adhere well and form an intimate contact with the surface of the HA specimens. The attached cells had typical osteoblast morphology, with a polygonal shape spread. Some cells have a long shape (inserted image). Cells securely attached to the surface indicate that the material surface provided a favourable environment for the cell to migrate and grow $[3,28]$. It is believed that contact and interaction between the cells are paramount for the 
differentiation process [27]. This is evident as the cells coverage in day 3 was greater than on day 1 as a result of the cell growth and proliferation, as seen in Figure $8 \mathrm{~b}$ and $\mathrm{c}$. The cells form bridges across the undulations and spread over them. In addition, the cells have spread and are in physical contact with each other (Figure 8b).

The result of cell proliferation of the HA sample and polystyrene control (culture disk) after 2, 4 and 6 days of culture are shown in Figure 9. As expected, the cell number for the control sample was higher compared to that of HA sample. A similar observation was also reported in a previous study [27]. However, the cell number steadily increased with time in all the samples. This indicated that the prepared sample is non-toxic and possessed good biocompatibility. The cell responses are affected by numerous factors including material chemistry, surface roughness, and surface topography $[3,27,29,30]$. A similar trend was also obtained in our previous study [3]. However, the difference in the cell number between the evaluated samples was due to the differences in the initial cell number and the cell counting protocol.

At day 6 of culture, there is insignificant difference in the cell number between the control and the HA samples although the control showed a slightly higher cell number as shown in Figure 9. It was reported that, at a certain period, cells formed a dense cell layer to cover the surface [29], followed by the expression of alkaline phosphatase and the synthesis, deposition, and mineralisation of a collagenous matrix [31].

The interaction of living cells with foreign materials is the key for understanding biocompatibility [32, 33]. The initial cellular event that takes place at the biomaterial interface is the natural adhesive interaction of the cells with the extracellular matrix. In the present work, based on the results obtained, it is evident that the synthesised HA promoted cell proliferation and growth, thus exhibiting excellent biocompatibility suitable for clinical applications.

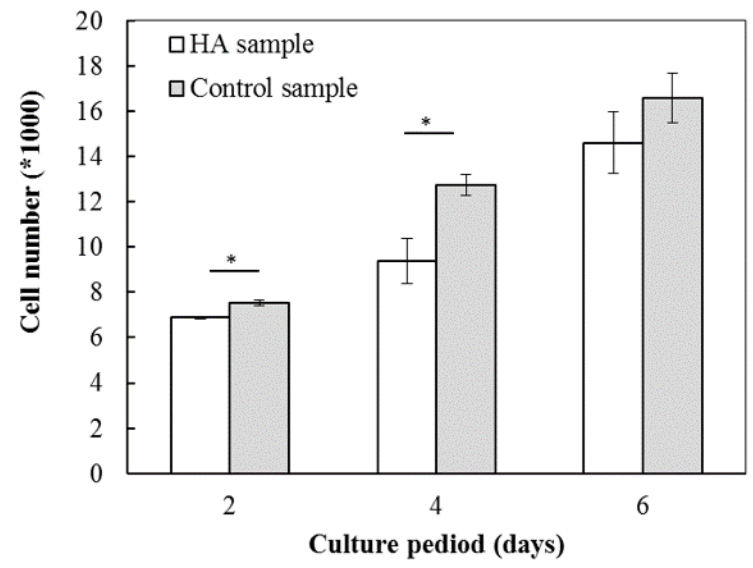

Figure 9. Proliferation of the cells on the HA and control samples $(* * p<0.05$ for comparisons between the indicated groups) 1 day, (c) 3 days.

\section{CONCLUSIONS}

In this study, it was revealed that the reactant concentration affects the thermal stability of the HA produced as well as the final morphology of the precipitates. Increasing the reactant concentration results in HA precipitates with higher pores in the sample. The decomposition of HA into TCP occurs at $1000{ }^{\circ} \mathrm{C}$ for an HA prepared at a reactant concentration of $1.5 \mathrm{~mol} \cdot \mathrm{L}^{-1}$ and at $1200^{\circ} \mathrm{C}$ for an HA prepared at reactant concentrations of 1.5 and $2 \mathrm{~mol} \cdot \mathrm{L}^{-1}$. Nonetheless, HA prepared at the reactant concentrations of $0.5 \mathrm{~mol} \cdot \mathrm{L}^{-1}$ and $1 \mathrm{~mol} \cdot \mathrm{L}^{-1}$ were found to be stable regardless of the calcination temperature. In particular, HA synthesised at $1.0 \mathrm{~mol} \cdot \mathrm{L}^{-1}$ composed of nano-particles, phase pure HA having excellent thermal stability. In addition, the cellular attachment and proliferation demonstrated that the HA prepared in this research work exhibited excellent biocompatibility suitable for biomedical applications.

\section{Acknowledgment}

This research work is supported by National Foundation for Science and Technology Development of Vietnam (Nafosted) [grant No. 104.03-2020.36].

\section{REFERENCES}

1. Bang L. T., Ishikawa K., Othman, R. (2011): Effect of silicon and heat-treatment temperature on the morphology and mechanical properties of silicon-substituted hydroxyapatite. Ceramics International, 37(8), 3637-3642. doi: 10.1016/j.ceramint.2011.06.023

2. Bang L. T., Long B. D., Othman R. (2014): Carbonate hydroxyapatite and silicon-substituted carbonate hydroxyapatite: synthesis, mechanical properties, and solubility evaluations. The Scientific World Journal, 2014, 969876. doi: 10.1155/2014/969876

3. Bang L.T., et al. (2015): Effects of silicate and carbonate substitution on the properties of hydroxyapatite prepared by aqueous co-precipitation method. Materials \& Design, 87, 788-796.doi:10.1016/j.matdes.2015.08.069

4. Sopyan I., et al. (2008): Synthesis of nano sized hydroxyapatite powder using sol-gel technique and its conversion to dense and porous bodies. Indian Journal of Chemistry, 47A: 1626-1631. http://nopr.niscair.res.in/ handle/123456789/2469

5. Ramesh S., et al. (2013): Nanocrystalline forsterite for biomedical applications: Synthesis, microstructure and mechanical properties. Journal of the Mechanical Behaviour of Biomedical Materials, 25, 63-69. doi: 10.1016/j.jmbbm.2013.05.008

6. Ramesh S., et al. (2012) Sintering behavior of hydroxyapatite prepared from different routes. Materials and Design, 34, 148-154. doi:10.1016/j.matdes.2011.08.011

7. Donadel K., et al. (2005): Hydroxyapatites Produced by Wet-Chemical Methods. Journal of the American 
Ceramic Society, 2005. 88, 2230-2235. doi:10.1111/j.15512916.2005.00433.x

8. Lazić S., et al. (2001): The effect of temperature on the properties of hydroxyapatite precipitated from calcium hydroxide and phosphoric acid. Thermochimica Acta, 374, 13-22. doi: 10.1016/s0040-6031(01)00453-1

9. Kothapalli C., et al. (2004): Influence of temperature and concentration on the sintering behavior and mechanical properties of hydroxyapatite. Acta Materialia, 52(19), 5655-5663. doi:10.1016/j.actamat.2004.08.027

10. Zhang H., Darvell B.W. (2011): Morphology and structural characteristics of hydroxyapatite whiskers: Effectof the initial $\mathrm{Ca}$ concentration, $\mathrm{Ca} / \mathrm{P}$ ratio and $\mathrm{pH}$. Acta Biomaterialia, 7(7), 2960-2968. doi:10.1016/j.actbio.2011.03.020

11. Ghosh S., et al. (2011): Synthesis of nano-sized hydroxyapatite powders through solution combustion route under different reaction conditions. Materials Science and Engineering: B, 176, 14-21. doi:10.1016/ j.mseb.2010.08.006

12. Arce H., et al. (2004): Effect of $\mathrm{pH}$ and Temperature on the Formation of Hydroxyapatite at Low Temperature By Decomposition of Ca-EDTA Complex. Polyhedron, 23, 1897-1901. doi:10.1016/j.poly.2004.04.021

13. Bianco A., et al. (2007): Thermal stability and sintering behaviour of hydroxyapatite nanopowders. Journal of Thermal Analysis and Calorimetry, 88(1), 237-243. doi: 10.1007/s10973-006-8011-6

14. Saeri M.R., et al. (2003): The wet precipitation process of hydroxyapatite. Materials Letters, 57(24), 4064-4069. doi:10.1016/S0167-577X(03)00266-0

15. Mostafa N. (2005): Characterization, thermal stability and sintering of hydroxyapatite powders prepared by different routes. Materials Chemistry and Physics, 94, 333-341. doi: 10.1016/j.matchemphys.2005.05.011

16. Ramesh S., et al. (2015): Characteristics and properties of hydoxyapatite derived by sol-gel and wet chemical precipitation methods. Ceramics International, 41, 1043410441. doi:10.1016/j.ceramint.2015.04.105

17. Ramesh S., et al. (2007): The effect of manganese oxide on the sinterability of hydroxyapatite. Science and Technology of Advanced Materials, 8, 257-263. doi:10.1016/ j.stam.2007.02.006

18. Tan C.Y., et al. (2013): Sintering and mechanical properties of $\mathrm{MgO}$-doped nanocrystalline hydroxyapatite. Ceramics International, 39, 8979-8983. doi:10.1016/ j.ceramint.2013.04.098

19. Feng W., et al. (2005): A simple sol-gel technique for preparing hydroxyapatite nanopowders. Materials Letters, 59(8),916-919. doi:10.1016/j.matlet.2004.08.041

20. Xiao X.F., et al. (2006):Characterization of hydroxyapatite/ titania composite coatings codeposited by a hydrothermalelectrochemical method on titanium. Surface and Coatings Technology, 200(14), 4406-4413. doi:10.1016/ j.surfcoat.2005.02.205
21. Tampieri A., et al. (1997): Sintering and characterization of HA and TCP bioceramics with control of their strength and phase purity. Journal of Materials Science: Materials in Medicine, 8(1), 29-37. doi: 10.1023/a:1018538212328

22. Reid J.W., et al. (2005): Phase formation and evolution in the silicon substituted tricalcium phosphate/apatite system. Biomaterials, 26(16), 2887-2897. doi:10.1016/ j.biomaterials.2004.09.005

23. Sayer M., et al. (2003): Structure and composition of silicon-stabilized tricalcium phosphate. Biomaterials, 24(3),369-382. doi:10.1016/S0142-9612(02)00327-7

24. Muralithran G, Ramesh S. (2000): The effects of sintering temperature on the properties of hydroxyapatite. Ceramics International, 26(2), 221-230. doi:10.1016/S02728842(99)00046-2

25. Chen P.-Y., et al. (2019): Evolution of the microstructural and mechanical properties of hydroxyapatite bioceramics with varying sintering temperature. Ceramics International, 45(13), 16226-16233. doi:10.1016/j.ceramint.2019.05.144

26. Ruys A.J., et al. (1995): Sintering effects on the strength of hydroxyapatite. Biomaterials, 16(5),409-415. doi:10.1016/0142-9612(95)98859-C

27. Popat K.C., et al. (2007): Influence of engineered titania nanotubular surfaces on bone cells. Biomaterials, 28(21), 3188-3197. doi:10.1016/j.biomaterials.2007.03.020

28. Shi X, et al. (2017): Interaction of hydroxyapatite nanoparticles with endothelial cells: internalization and inhibition of angiogenesis in vitro through the PI3K/Akt pathway. International Journal of Nanomedicine, 12, 57815795. doi: 10.2147/IJN.S140179

29. Magallanes-Perdomo M., et al. (2010): In vitro study of the proliferation and growth of human bone marrow cells on apatite-wollastonite-2M glass ceramics. Acta Biomaterialia, 6(6), 2254-2263. doi:10.1016/j.actbio.2009.12.027

30. Zareidoost A., et al. (2012): The relationship of surface roughness and cell response of chemical surface modification of titanium. Journal of materials science. Materials in medicine, 23(6), 1479-1488. doi:10.1007/ s10856-012-4611-9

31. Hott, M., et al. (1997): Proliferation and differentiation of human trabecular osteoblastic cell on hydroxyapatite. Journal of Biomedical Materials Research, 37, 508-516. doi:10.1002/(sici)1097-4636(19971215)37:4<508::aidjbm $9>3.0$. co; $2-p$

32. Shi, X., et al. (2012): Surface modification of titanium by hydrothermal treatment in Mg-containing solution and early osteoblast responses. Journal of Materials Science: Materials in Medicine, 23(5),1281-1290. doi:10.1007/ s10856-012-4596-4

33. Bang, L., et al., (2020): Biological responses of MC3T3-E1 on calcium carbonate coatings fabricated by hydrothermal reaction on titanium. Biomedical Materials, 15(3), 035004. doi:10.1088/1748-605X/ab6939 